\title{
Rate dynamics of the retina-LGN connection
}

\author{
Thomas Heiberg*', Tom Tetzlaff, Birgit Kriener, Hans E Plesser, Gaute T Einevoll \\ From Twentieth Annual Computational Neuroscience Meeting: CNS*2011 \\ Stockholm, Sweden. 23-28 July 2011
}

Firing-rate models provide a practical tool for studying the dynamics of trial- or population-averaged neuronal signals. The derivation or extraction of such models through investigation of the firing-rate response characteristics of ensembles of neurons has been the subject of several studies (see references in [1]). The majority of these focused on neurons that receive input spikes at a high rate through weak synapses (diffusion approximation). For many neural systems, however, this assumption cannot be justified. One example in the early visual system is the lateral geniculate nucleus (LGN), where synapses between retinal ganglion cells and relay cells are so strong that single retinal spikes can initiate action potentials in the thalamic targets.
Using a comprehensive numerical approach, we recently studied the firing-rate response properties of leaky integrate-and-fire (LIF) neurons receiving current input through strong synapses [1]. Input spike trains were modeled as inhomogeneous Poisson point processes with sinusoidally modulated rate. Average rates, modulation amplitudes, and phases of the period-averaged spike responses were measured for a broad range of stimulus, synapse, and neuron parameters, cf Fig. 1. We found that the resulting responses could be described well by a linear first-order low-pass filter over a wide range of model parameters. Combining this filter with the nonlinear response characteristic for stationary inputs, we constructed a linear-nonlinear firing-rate

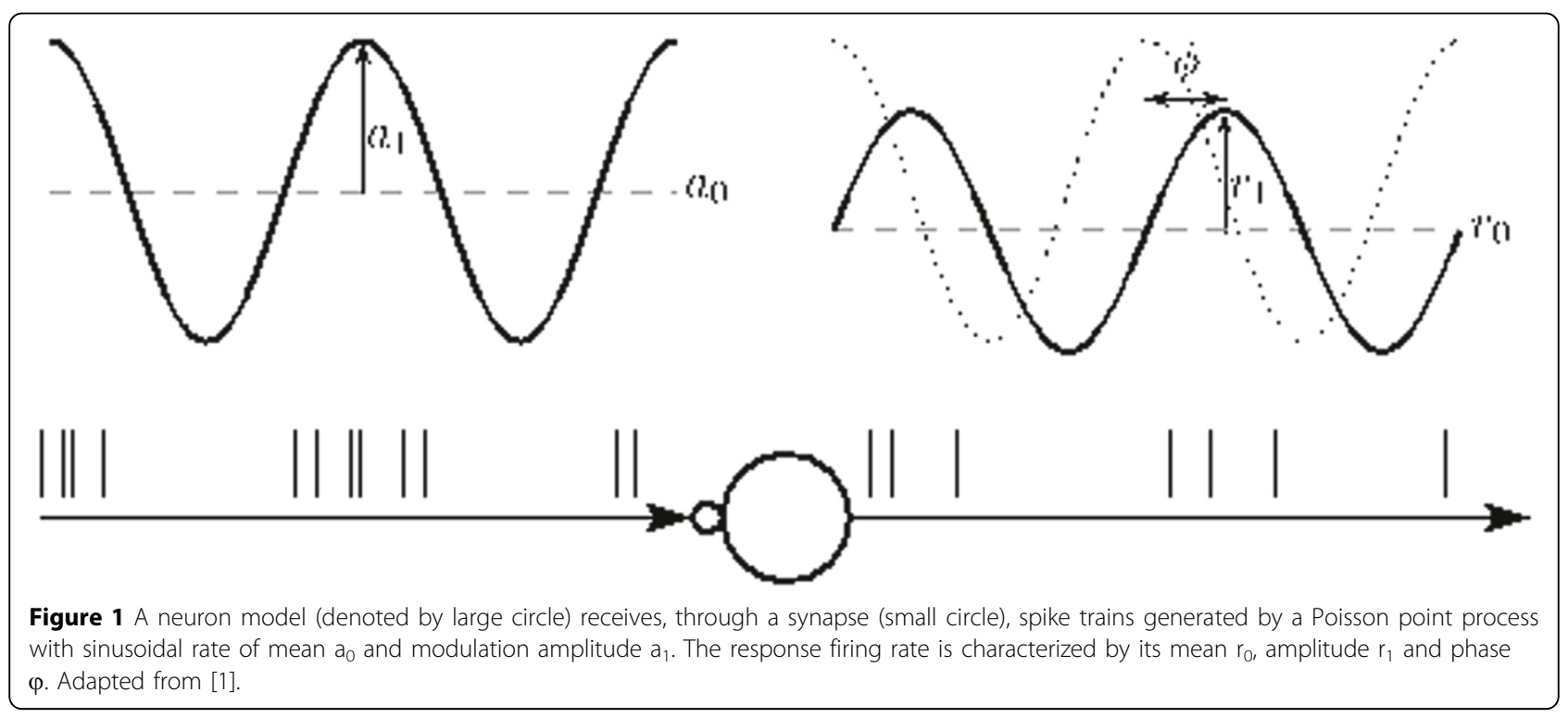

* Correspondence: thomas.heiberg@umb.no
Dept. of Mathematical Sciences \& Technology, Norwegian Univ. Life
Sciences, 1432 Aas, Norway

\section{Biomed Central}

() 2011 Heiberg et al; licensee BioMed Central Ltd. This is an open access article distributed under the terms of the Creative Commons Attribution License (http://creativecommons.org/licenses/by/2.0), which permits unrestricted use, distribution, and reproduction in any medium, provided the original work is properly cited. 
model, which accurately predicted the population response for a variety of non-sinusoidal test stimuli.

In the present study, we use the same approach to investigate whether linear-nonlinear firing-rate models can capture equally well the firing rate properties of LGN relay neuron models that have been fitted to experimental data [2,3]. Models investigated include more "realistic" ones with conductance-based synaptic and after-hyperpolarizing currents [2] as well as more abstract spike-response models [3,4].

\section{Acknowledgements}

Supported by the Research Council of Norway (eVita [eNEURO], NOTUR). Simulations and data analysis were carried out using the NEST simulation tool (http://www.nest-initiative.org) and Python (http://www.python.org).

Published: 18 July 2011

\section{References}

1. Nordlie E, Tetzlaff T, Einevoll GT: Rate Dynamics of Leaky Integrate-andFire Neurons with Strong Synapses. Front Comput Neurosci 2010, 4:149.

2. Casti A, Hayot F, Xiao Y, Kaplan E: A simple model of retina-LGN transmission. J Comput Neurosci 2008, 24:235-252.

3. Carandini $M$, Horton J, Sincich $L$ : Thalamic filtering of retinal spike trains by postsynaptic summation. J Vision 2007, 7:20.

4. Gerstner W, Kistler W: Spiking Neuron Models. Cambridge University Press, Cambridge, UK; 2002.

doi:10.1186/1471-2202-12-S1-P90

Cite this article as: Heiberg et al:: Rate dynamics of the retina-LGN connection. BMC Neuroscience 2011 12(Suppl 1):P90.

\section{Submit your next manuscript to BioMed Central} and take full advantage of:

- Convenient online submission

- Thorough peer review

- No space constraints or color figure charges

- Immediate publication on acceptance

- Inclusion in PubMed, CAS, Scopus and Google Scholar

- Research which is freely available for redistribution

Submit your manuscript at www.biomedcentral.com/submit 